\title{
Is Time Ripe for a Currency Union in Emerging East Asia?: The Role of Monetary Stabilization
}

\author{
Marcelo Sánchez \\ European Central Bank
}

\begin{abstract}
This paper assesses the prospects for monetary integration between Emerging East Asian (EEA) economies. We develop a simple analytical framework for currency unions of small open economies. The empirical analysis looks at a number of supply-side characteristics of EEA countries highlighted by the model, distinguishing between aggregate and tradable sector structural features. Moreover, we discuss the evidence on the cross-country correlation of disturbances hitting the region. Our study indicates that, at present, EEA economies exhibit a high degree of cross-country supply diversity, while there is no compelling evidence that shocks are highly correlated across the region.
\end{abstract}

- JEL classification: E52, E58, F33, F40

- Keywords: East Asia, Emerging economies, Currency union, Stabilization

\section{Introduction}

There is a wide-ranging and increasing literature on the experience and prospects of monetary integration around the globe. One of the areas in the world that has attracted considerable attention in recent years is East Asia, with many studies having investigated whether the region could be suitable for embarking in further monetary cooperation and eventually forming a currency union. Among the reasons for this interest, we can mention the following three. First, East Asian economies exhibit high shares of intra-regional trade. Second, there is evidence of

\footnotetext{
*Corresponding address: European Central Bank. Kaiserstr. 29. D-60311. Frankfurt am Main. Germany. Phone: +49691344 6531, Fax: +49691344 6353, E-mail: marcelo.sanchez@ecb.int (c)2006-Center for International Economics, Sejong Institution, All Rights Reserved.
} 
increasing financial market interdependence over recent years. Third, there have been a number of initiatives regarding financial cooperation following the Asian crisis of 1997-1998. Such cooperation most notably includes the Chiang Mai initiative of May 2000, a network of bilateral swap arrangements established among ASEAN +3 countries for the case of speculative attacks against their currencies. Enhanced interaction via trade and financial flows has proved instrumental in leading to monetary unions in previous historical experiences.

Most of the literature on the monetary integration of small open economies is of an empirical nature. It is often rooted in theoretical underpinnings as given by optimal currency area criteria. The starting point is to realize that the single most important cost implied by full monetary integration consists of giving up independent monetary policy for inflation and output stability. Analysts discuss how currency union's stabilization properties and individual countries' macroeconomic performance are affected by heterogeneity in key structural parameters and the nature of disturbances. In the case of countries in the emerging East Asia (EEA) region,1 the discussion of the nature of shocks has appeared in many different contexts. Naturally, this has been at the heart of the assessment of the region's suitability for monetary union since Bayoumi and Eichengreen's (1994) seminal work. Asymmetric shocks are also seen to underlie the collapse of fixed exchange rate systems in the region at the time of the Asian crisis of 1997-1998. In this regard, some authors have analyzed the role of swings in the yen-dollar rate in the outbreak of in countries that were in practice pegging to the dollar, or attaching high weights to the dollar in the conduct of their exchange rate policy.

Putting into perspective the stabilization costs implied by monetary union, specialists have pointed to other factors playing a major role. For instance, some studies find evidence that currency unions have favorable credibility and tradeenhancing effects. The latter has been emphasized in the influential work of Rose $(2001,2002)$, who reports a positive impact of currency unions on trade. ${ }^{2}$ More generally, favorable effects on potential output via trade and financial integration have led analysts to assess more positively the possibility of a country joining a currency union even before full economic integration is achieved.

\footnotetext{
${ }^{1}$ EEA is defined as the sum of China, Hong Kong, India, South Korea (henceforth Korea), Taiwan and ASEAN-5. The latter group is composed of Indonesia, Malaysia, Philippines, Singapore and Thailand.

${ }^{2}$ For a review of studies finding similar results, see Rose (2004). A common currency can also lead to welfare gains by fostering financial deepening across the union. Plummer and Click (2005) make the case for a common ASEAN basket of currencies as a way to facilitating cross-issuance of bonds.
} 
The object of this paper is twofold. First, we take a step in developing theoretical results on currency unions between small open economies. The focus on small open economies implies that we neglect spillovers across countries of the type analyzed by Lane's (2000) two-country model, and Buiter et al.'s (1998a, 1998b) core-periphery approach. We also abstract from defining the concrete common unit of account being used. ${ }^{3}$ Second, we look at data for EEA economies to assess some of the model implications regarding the region's suitability for monetary integration. By looking at EEA countries, we follow most of the studies assessing prospects of currency union in Asia.

To achieve our first goal, we extend recent work on currency unions that is rooted in the standard time inconsistency literature (see Lane, 2000, Alesina and Barro, 2002, Ca' Zorzi and De Santis, 2004, Ca' Zorzi et al., 2005, Sánchez, 2005 b). We do so in the following ways. First, we model decisions about the interest rate, which is, realistically, the union-wide monetary policy instrument. ${ }^{4}$ Second, we study a broad set of shocks as given by supply, demand and risk premium disturbances while also allowing inflation targets to play a role. As in Lane (2000), shocks can adopt three different features: to be common, asymmetric or idiosyncratic. Third, we explicitly model imported inflation. Members states may face different imported inflation due to: i) different commodity compositions of trade; and ii) different effective exchange rates arising from different geographical compositions of trade. ${ }^{5}$ Fourth, we allow supply schedules to differ across countries.

The structure of the rest of the paper is as follows. In section 2, we lay out a simple model to study monetary policy in a currency union. Section 3 applies some lessons from the model to EEA economies. Section 4 concludes.

\footnotetext{
${ }^{3}$ The literature on EEA has proposed different anchors such as the yen (Kwan, 2001), the US dollar (Mundell, 2002), the renminbi (Hefeker and Nabor, 2005) or a common basket of major currencies (Williamson, 2002, Mussa et al., 2000). Alesina et al. (2002) find no compelling case for a yen block.

${ }^{4}$ Formerly, the focus has been on the inflation outcome (Ca'Zorzi and De Santis, 2004, Ca' Zorzi et al., 2005), or in addition on money supply as the authorities' policy instrument (Lane, 2000).

${ }^{5} \mathrm{~A}$ role for geographical composition of trade also features in Ogawa and Ito (2000). They show that an EEA economy's choice of the exchange rate (or weights in a basket comprising the US, Japan and an emerging regional partner) is dependent on the neighbouring EEA country's.
} 


\section{Monetary Policy in a Currency Union ${ }^{6}$}

Let us consider a simple model of a monetary union between small open economies. Four equations describe the private sector in each of the union's members $i=1,2, \ldots, N$ :

$$
\begin{gathered}
y_{i}=\alpha_{i}\left(\pi_{i}-\pi_{i}^{e}\right)+\varepsilon_{i} \\
y_{i}=\beta_{i} r_{i}-\delta_{i} e_{i}+\varsigma_{i} \\
r_{i}=\theta_{i} e_{i}+\varepsilon_{i}^{f} \\
r_{i}=R-\pi_{i,+1}^{e}
\end{gathered}
$$

where all variables are expressed as deviations from steady state values and, with the exception of the nominal and real interest rate, are in logarithms. Constants have been normalized to zero. All parameters are assumed to be positive. All shocks are of the zero-mean, constant variance, type, and serially correlated. They are assumed to be uncorrelated with each other for all $i$, but allowed to be correlated across countries.

Equation (1) is a simple aggregate supply schedule which states that output $\left(y_{i}\right)$ responds positively to surprises from the last period's expectations of the inflation level $\left(\pi_{i}-\pi_{i}^{e}\right)$. In (2), aggregate demand is decreasing in the real interest rate $\left(r_{i}\right)$. Output also depends negatively on the real exchange rate $\left(e_{i}\right)$. Note that an increase in $e_{i}$ denotes an appreciation of the real exchange rate. Equation (3) posits a positive relation between interest rates and exchange rates that can be interpreted to mean that higher interest rates encourage capital inflows, which leads to an appreciation. Other determinants of exchange rates, such as investor confidence and expectations, are captured by the error $\varepsilon_{i}^{f}$. Finally, (4) is the Fisher equation defining the real interest rate as a difference between nominal short-term interest rate $R$ (decided by the currency union's monetary authority) and the current period's expectation of future inflation, $\pi_{i,+1}^{e} \cdot 7$

\footnotetext{
${ }^{6} \mathrm{~A}$ more detailed analysis can be found in the working paper version (Sánchez, 2005a).

${ }^{7}$ Positive values for $\varepsilon_{i}$ and $\zeta_{i}$ represent favorable supply and demand shocks, respectively, while a positive value for $\varepsilon_{i}^{f}$ is interpreted to reflect an adverse risk premium shock.
} 
We close the model by deriving the monetary policy reaction function. By definition, there is but a single monetary policy for a currency union. We assume that the monetary authority of the currency union cares equally about each member country. The central bank minimizes a loss function given by

$$
L_{u}=\frac{1}{2}\left[y_{u}^{2}+\chi\left(\pi_{u}-\pi_{u}\right)^{2}\right]
$$

In (5), the central bank penalizes departures of union-wide output and inflation from desired values set to zero and $\pi_{u}$, respectively. ${ }^{8}$ The latter is assumed to adopt a fixed and credible value. The monetary authority has no incentive to surprise the private sector with inflation, and there thus is no inflation bias. Parameter $\chi$ is the weight of inflation aversion relative to the aim of achieving output stabilization.

We assume that the union's public knows $\alpha_{i}, \beta_{i}, \delta_{i}, \theta_{i}, \chi, \tilde{\pi}_{i}$ the distribution of the disturbances $\varepsilon_{i}, \varsigma_{i}$ and $\varepsilon_{i}^{f}$, for all $i$, and that it observes the nominal interest and exchange rates. Moreover, the central bank, producers and foreign exchange market participants are assumed to all observe current output, prices and nominal exchange rates. In this context, a state-contingent reaction function is feasible.

Before solving the model, let us define three types of shocks, namely: (i) asymmetric; (ii) idiosyncratic; and (iii) common. ${ }^{9}$ Shocks are normalized to be of unit magnitude for country $I$, which is the focus of our comparisons across regimes. Asymmetric shocks are defined to be shocks such that they add up to zero at the currency union level; in particular, country $I$ of size $\varphi_{I}$ is assumed to face a shock equal to 1 , while each of the remaining countries faces a shock equal to $-\varphi_{I} /\left(1-\varphi_{I}\right)$. Idiosyncratic shocks are those in which shocks to country $I$ equal 1 , and shocks to any other country equal 0 . Finally, common shocks are defined to be shocks such that they add up to one at the currency union level; in particular, all countries are assumed to face a shock equal to 1 . In terms of the unconditional cross-country covariances in (9), an asymmetric shock implies a negative such covariance between country $I$ and the remaining countries in the union, an idiosyncratic shock amounts to a zero covariance between country $I$ and the remaining countries in the union, and a common shock means that the covariance between country $I$ and each of the remaining countries in the union is 1 .

${ }^{8}$ Union-wide variables are weighted averages using weights $\varphi_{i} \in(0,1)$.

${ }^{9}$ Frankel and Rose (1998) argue that trade integration makes common shocks more likely. Lee et al. (2004) analyse whether also the nature of this trade (inter- versus intra-industry) matters for East Asia. 
To solve the model, we take averages of (1) over the union members and minimize (5) subject to private sector behaviour as defined by the rest of the model. This allows us to derive, under rational expectations, the monetary policy reaction function:

$$
R=\frac{1}{A}\left[-a \sum \varphi_{i} \alpha_{i}^{\prime} \varepsilon_{i}+\sum \varphi_{i} \alpha_{i}^{\prime} b_{i} \varsigma_{i}+\sum \varphi_{i} \alpha_{i}^{\prime} c_{i} \varepsilon_{i}^{f}+\sum \varphi_{i} \alpha_{i}^{\prime} b_{i} \tilde{\pi}_{i}\right]
$$

where

$A \equiv \sum \varphi_{i} \alpha_{i}^{\prime} d_{i}, \alpha_{i}^{\prime} \equiv 1^{\prime} / \alpha_{i}, a \equiv \chi^{\prime}\left(\alpha_{u}^{2}+\chi\right), b_{i} \equiv 1+\alpha_{u}\left(\alpha_{i}-\alpha_{u}\right) /\left(\alpha_{u}^{2}+\chi\right)$, $c_{i} \equiv d_{i} \delta_{i} / \theta_{i}$ and $d_{1} \equiv b_{1}\left(\beta_{i}+\delta_{i} / \theta_{i}\right)$. Expression (6) shows how the nominal interest rate reacts to aggregates of shocks and inflation targets at the country level. As expected, $R$ is raised in response to adverse supply and risk premium shocks, favorable demand shocks and higher desired inflation, judging from the aggregates that appear in (6).

We use (6), alongside (1) through (4), to derive expressions of union-wide output and inflation in terms of aggregates of country-level shocks and inflation target levels:

$$
\begin{gathered}
y_{u}=-\sum \varphi_{i} \alpha_{i}^{\prime} f \varepsilon_{i}+\sum \varphi_{i} g_{i} \varsigma_{i}+\sum \varphi_{i} h_{i} \varepsilon_{i}^{f}+\sum \varphi_{i} k_{i} \tilde{\pi}_{i} \\
\pi_{u}=\tilde{\pi}_{u}-\sum \varphi_{i} \alpha_{i}^{\prime} l \varepsilon_{i}+\sum \varphi_{i} m_{i} \varsigma_{i}+\sum \varphi_{i} n_{i} \varepsilon_{i}^{f}+\sum \varphi_{i} \tilde{p}_{i} \tilde{\pi}_{i}
\end{gathered}
$$

where $f \equiv B a / A, \quad g_{i} \equiv 1-B \alpha_{i}^{\prime} b_{i} / A, \quad h_{i} \equiv \delta_{i}\left(1-B \alpha_{i}^{\prime} d_{i} / A\right) / \theta_{i}, k_{i} \equiv\left(\beta_{i}+\delta_{i} / \theta_{i}\right)$ $-B \alpha_{i}^{\prime} b_{i} / A, l \equiv 1-f, m_{i} \equiv 1-B b_{i} / A, n_{i} \equiv \delta_{i}\left(1-B d_{i} / A\right) / \theta_{i}, p_{i} \equiv\left(\beta_{i}+\delta_{i} / \theta_{i}\right)-$ $B b_{i} / A$, and $B \equiv \sum \varphi_{i} \alpha_{i}^{\prime}\left(\beta_{i}+\delta_{i} / \theta_{i}\right)$. In equations (7) and (8), country-level shocks and inflation targets contribute to determine $y_{u}$ and $\pi_{u}$. These effects reflect the relative size of the countries involved (as given by $\varphi_{i}$ ) and the reactions in each of them as influenced by structural parameters.

Replacing (7) and (8) into (6), and taking unconditional expectations, leads to the expected loss function: ${ }^{10}$

$$
E\left(L_{u}\right)=\frac{a}{2}\left[s^{2} \sum \varphi_{i}^{2} \alpha_{i}^{2} \sigma_{\varepsilon_{i}}^{2}+\sum \varphi_{i}^{2} \alpha_{i}^{2} t_{i}^{2} \sigma_{\zeta_{i}}^{2}+\sum \varphi_{i}^{2} \alpha_{i}^{2} u_{i}^{2} \sigma_{\varepsilon_{i}^{\prime}}^{2}+\sum \varphi_{i}^{2} \alpha_{i}^{2} v_{i}^{2} \pi_{i}^{2}+\Phi\right]
$$

\footnotetext{
${ }^{10}$ For simplicity, we assume that the constant equals zero, which holds under a wide range of plausible parameter values.
} 


$$
\begin{gathered}
\text { where, } \Phi \equiv \sum_{i \neq j} \varphi_{i} \varphi_{j} \alpha_{i}^{\prime} \alpha_{j}^{\prime} \Phi_{l j}, \Phi_{l j} \equiv \alpha_{u}^{2} \sigma_{\varepsilon_{i}} \sigma_{\varepsilon_{j}}+t_{i} t_{j} \sigma_{s_{i}} \sigma_{s_{j}}+u_{i} u_{j} \sigma_{\varepsilon_{i}^{\prime}} \sigma_{\varepsilon_{j}^{\prime}}+\alpha_{u} \\
+\alpha_{u} u_{j} \sigma_{\varepsilon_{i} \varepsilon_{j}^{\prime}}+t_{i} u_{j} \sigma_{s_{i} \varepsilon_{j}^{\prime}}+v_{i} v_{j} \pi_{i} \pi_{j}, \quad t_{i} \equiv \alpha_{i}-\alpha_{u}, \quad u_{i} \equiv \delta_{i}\left(\alpha_{i}-\alpha_{u}\right) / \theta_{i} \text {, and }
\end{gathered}
$$

$v_{i} \equiv\left(\beta_{i}+\delta_{i} / \theta_{i}\right)\left(\alpha_{i}-\alpha_{u}\right)$. We denote the unconditional variance of any disturbance $x$ by $\sigma_{x}^{2}$, and the unconditional covariance between any pair $(x, z)$ by $\sigma_{x z}$.

In (9), $E\left(L_{u}\right)$ reacts to supply shocks as follows. When the latter are idiosyncratic, $E\left(L_{u}\right)$ is a positive function of the variances of these shocks in each member country. These variances are weighted by the square of each participant's size and also affected by the square of the supply schedule parameter $\alpha_{i}^{\prime}$. The variance of supply shocks in a given country has a limited impact on the union insofar as this country is not too large. For common and asymmetric supply disturbances, welfare analysis calls for inspection of the signs of the cross-country covariances of shocks in $\Phi$. Supply shocks have a positive welfare contribution if they are negatively correlated and a negative welfare contribution if shocks are positively correlated. The intuition is that asymmetric supply shocks tend to offset each other, thereby limiting the need for interest rate changes.

Demand and risk premium shocks have no impact on welfare if the supply slope parameter is uniform across the union, and neither do country-specific inflation targets $\tilde{\pi}_{i}$. Supply slope parameters are likely to exhibit cross-country variation, the more so the more they differ in their economic structures. In this case, demand and risk premium disturbances of the idiosyncratic and asymmetric types hamper a currency union's stabilization performance. In contrast, common demand and risk premium disturbances exhibit a built-in dampening factor that increases welfare in a monetary union. To see this, note that for any country $I$ with parameter $\alpha_{I}$ above union's average $\alpha_{u}$ undergoing a shock of size 1 , there must be at least some country $J\left(\right.$ with $I \neq J$ ) with parameter $\alpha_{J}$ below union's average $\alpha_{u}$ also experiencing a shock of size 1 . In this case, a positive $I$ - $J$ cross-country covariance of demand and risk premium shocks contributes to improve welfare by reducing $\Phi$. Common disturbances require less of an interest rate change to deliver a given offset of the macroeconomic impact of shocks.

Finally, (9) indicates that a configuration in which the union's larger countries have lower desired inflation than that targeted by smaller countries contributes positively to the stabilization performance of a currency union. The opposite result obtains if the distribution of $\tilde{\pi}_{i}$ across countries is reversed. 
To conclude, the cross-country distribution of shocks and inflation targets matters for a currency union's stabilization properties. Supply shocks have a positive welfare contribution if they are negatively correlated and a negative contribution if they are positively correlated. In the benchmark case of a uniform supply slope parameter, demand and risk premium shocks across countries fail to have an impact on welfare, and so do country-specific inflation targets. In the likely case when the output-inflation trade-off exhibits cross-country variation, demand and risk premium disturbances of the idiosyncratic and asymmetric types reduce a currency union's welfare. Common shocks pushing demand and risk premia up exhibit a built-in dampening factor, thereby favoring the case for monetary stabilization in a currency area.

\section{Monetary Integration Prospects in Emerging East Asia}

The welfare analysis of section 2 highlights the importance of several structural aspects for a currency union's stabilization performance. It also motivates the study of following three aspects of EEA economies. First, in subsection 3.1 we gauge the degree of similarity or heterogeneity in supply conditions. As we have stressed, the gap between country-level supply parameter and its union-wide counterpart, $\alpha_{i}-\alpha_{u}$, is important in judging welfare effects of demand and risk aversion shocks, as well as being a possibly amplifying factor to inflation target differentials. Gaps $\alpha_{i}-\alpha_{u}$ can be the result of non-tradable sector specificities, or stem from differential degrees of trade openness. In addition to slope parameter $\alpha_{i}$, other supply determinants such as expected inflation $\pi_{i}^{e}$ and productivity shock term $\varepsilon_{i}$ are affected by structural factors once more concerning either the non-tradable or tradable sector. ${ }^{11}$ Moreover, the size of a given country is important. While smaller countries contribute by less to union-wide shocks, while they are the ones standing the most to lose from idiosyncratic or asymmetric shocks. The occurrence of these types of shocks in larger countries also affect their welfare but, due to the latter's larger size, they are in a better position to benefit from stabilization policy. Second, subsection 3.2 turns to correlations of shocks across countries. Such correlations can affect welfare at the currency-union level in different ways depending on parameter

\footnotetext{
${ }^{11}$ Tradable inflation can in part be explained by country-specific features relating to either idiosyncratic commodity compositions of international trade (abstracting from cross-country differential inflation for a given type of tradable goods) or idiosyncratic weights attached to different trading partners. The latter factors have the potential to create differential effective exchange rate effects within a currency union as a result of swings in union's extra-area bilateral exchange rates.
} 
values as well as the nature of the shocks themselves. Third, in subsection 3.3 we examine the role of inflation targets.

\section{A. Supply-side characteristics and size}

Before turning to the study of size and supply-side characteristics of EEA countries, it is worth noting that, over the last fifteen years, the region has registered a strong economic performance as well as gone through considerable structural change. Indeed, EEA economies have expanded on a sustained basis over the period, thereby increasing their share in global GDP from some $11.2 \%$ in 1990 to $20.2 \%$ in 2004 (Table 1). Almost $85 \%$ of this increase can be attributed to China, whose share in world output rose from $5.9 \%$ to $13.5 \%$ over the same period. The aggregate of ASEAN-5 countries increased its share in global GDP by around $1 \%$ over the same period, now accounting for about $5 \%$ of the total. Moreover, EEA's economic expansion has been outward-oriented in nature. The share of the region's exports in the world total has risen from $12.4 \%$ to $20.4 \%$ between 1990 and 2004 (Table 2). Over $60 \%$ of this improvement stems from China's outstanding export growth. Most other countries in the region have also managed to exhibit a strong increase in their penetration of foreign markets.

Starting with the sizes of EEA countries, they look rather uneven, ranging from larger China to the smaller economies of Malaysia, Philippines and Hong Kong. The remaining economies stand in an intermediate position. If EEA were a currency union, the monetary authorities would tend to react more strongly to shocks hitting China, followed by those affecting economies such as Korea, Singapore or Taiwan. The smaller economies in the union would have much less of an impact on the union's decisions, being left to face a larger share of the shocks hitting them.

We now turn to the analysis of some indicators that help us gauge the degree of similarity of EEA supply structures. We first look at aggregate supply characteristics of different EEA countries, before turning to specific features regarding the tradable sector. The more aggregate analysis of EEA supply characteristics includes the stage of development as measured by per capita income, and the shares of different sectors in the economy. ${ }^{12}$ Per capita income has risen across the region since 1990 with no signs of deceleration from the pace exhibited prior to that (Table 3 ). In

\footnotetext{
${ }^{12}$ Sánchez (2005a) also examines competitiveness surveys measuring the quality of institutions and preparedness for technological advance. The rankings tend to reflect the degree of economic development, with economies at a more advanced stage of development, such as Singapore, Hong Kong, Korea and Taiwan, also exhibiting higher scores in most competitiveness indicators.
} 
Table 1. Emerging Asia share in world real GDP

in $\%$, ppp-adjusted

\begin{tabular}{|c|c|c|c|c|c|c|c|c|c|c|c|c|c|c|c|}
\hline & 1990 & 1991 & 1992 & 1993 & 1994 & 1995 & 1996 & 1997 & 1998 & 1999 & 2000 & 2001 & 2002 & 2003 & 2004 \\
\hline Emerging East Asia & 11.2 & 12.1 & 13.1 & 14.2 & 15.2 & 16.1 & 16.8 & 17.2 & 17.1 & 17.6 & 18.1 & 18.6 & 19.3 & 19.8 & 20.2 \\
\hline China & 5.9 & 6.4 & 7.2 & 8.0 & 8.7 & 9.3 & 9.8 & 10.3 & 10.8 & 11.2 & 11.5 & 12.1 & 12.7 & 13.1 & 13.5 \\
\hline Hong Kong & 0.4 & 0.4 & 0.4 & 0.4 & 0.4 & 0.4 & 0.4 & 0.4 & 0.4 & 0.4 & 0.4 & 0.4 & 0.4 & 0.4 & 0.4 \\
\hline Korea & 1.4 & 1.5 & 1.6 & 1.7 & 1.7 & 1.8 & 1.9 & 1.9 & 1.6 & 1.5 & 1.5 & 1.6 & 1.6 & 1.6 & 1.6 \\
\hline Taiwan & 0.8 & 0.8 & 0.9 & 0.9 & 0.9 & 1.0 & 1.0 & 1.0 & 1.0 & 1.0 & 1.0 & 1.0 & 1.0 & 1.0 & 1.0 \\
\hline ASEAN-5 & 2.8 & 3.0 & 3.1 & 3.3 & 3.4 & 3.6 & 3.7 & 3.7 & 3.3 & 3.4 & 3.5 & 3.5 & 3.6 & 3.7 & 3.7 \\
\hline Indonesia & 0.3 & 0.3 & 0.4 & 0.4 & 0.4 & 0.4 & 0.5 & 0.5 & 0.4 & 0.4 & 0.5 & 0.4 & 0.4 & 0.5 & 0.5 \\
\hline Malays & 0.2 & 0.2 & 0.2 & 0.2 & 0.2 & 0.2 & 0.2 & 0.2 & 0.2 & 0.2 & 0.3 & 0.2 & 0.2 & 0.2 & 0.2 \\
\hline Philippines & 0.2 & 0.2 & 0.2 & 0.2 & 0.2 & 0.2 & 0.2 & 0.2 & 0.2 & 0.2 & 0.2 & 0.2 & 0.2 & 0.2 & 0.2 \\
\hline & 1.3 & 1.4 & 1.4 & 1.5 & 1.5 & 1.6 & 1.7 & 1.7 & 1.5 & 1.6 & 1.7 & 1.7 & 1.8 & 1.8 & 1.8 \\
\hline Thailand & 0.8 & 0.9 & 0.9 & 1.0 & 1.1 & 1.1 & 1.1 & 1.1 & 0.9 & 0.9 & 0.9 & 0.9 & 1.0 & 1.0 & 0.9 \\
\hline
\end{tabular}

Source: IMF's World Economic Outlook.

Table 2. Emerging East Asia share in world exports

in $\%$

\begin{tabular}{|c|c|c|c|c|c|c|c|c|c|c|c|c|c|c|c|}
\hline & 1990 & 1991 & 1992 & 1993 & 1994 & 1995 & 1996 & 1997 & 1998 & 1999 & 2000 & 2001 & 2002 & 2003 & 2004 \\
\hline Emerging East Asia & 12.4 & 13.7 & 14.5 & 16.2 & 17.0 & 17.3 & 17.3 & 17.7 & 17.0 & 17.2 & 18.5 & 17.8 & 18.6 & 19.0 & 20.4 \\
\hline China & 1.9 & 2.1 & 2.3 & 2.5 & 2.8 & 2.9 & 2.9 & 3.3 & 3.4 & 3.4 & 3.9 & 4.3 & 5.1 & 5.8 & 6.9 \\
\hline Hong Kong & 2.4 & 2.8 & 3.2 & 3.6 & 3.6 & 3.4 & 3.4 & 3.4 & 3.2 & 3.1 & 3.2 & 3.1 & 3.1 & 3.0 & 2.9 \\
\hline Korea & 2.0 & 2.1 & 2.1 & 2.3 & 2.4 & 2.6 & 2.6 & 2.6 & 2.5 & 2.5 & 2.7 & 2.4 & 2.5 & 2.6 & 2.7 \\
\hline Taiwan ${ }^{1)}$ & 2.0 & 2.2 & 2.2 & 2.3 & 2.2 & 2.2 & 2.2 & 2.2 & 2.0 & 2.1 & 2.3 & 2.0 & 2.0 & 1.9 & 1.9 \\
\hline ASEAN-5 & 4.1 & 4.6 & 4.8 & 5.5 & 6.0 & 6.1 & 6.2 & 6.2 & 5.9 & 6.0 & 6.4 & 5.9 & 5.9 & 5.7 & 6.0 \\
\hline Indonesia & 0.8 & 0.8 & 0.9 & 1.0 & 0.9 & 0.9 & 0.9 & 1.0 & 0.9 & 0.9 & 1.0 & 0.9 & 0.9 & 0.8 & 0.8 \\
\hline Malaysia & 0.9 & 1.0 & 1.1 & 1.3 & 1.4 & 1.5 & 1.5 & 1.4 & 1.4 & 1.5 & 1.5 & 1.4 & 1.5 & 1.4 & 1.5 \\
\hline Philippines & 0.2 & 0.3 & 0.3 & 0.3 & 0.3 & 0.3 & 0.4 & 0.5 & 0.5 & 0.6 & 0.6 & 0.5 & 0.5 & 0.5 & 0.5 \\
\hline Singapore & 1.6 & 1.7 & 1.7 & 2.0 & 2.3 & 2.3 & 2.4 & 2.3 & 2.0 & 2.0 & 2.2 & 2.0 & 1.9 & 1.9 & 2.0 \\
\hline Thailand & 0.7 & 0.8 & 0.9 & 1.0 & 1.1 & 1.1 & 1.1 & 1.0 & 1.0 & 1.0 & 1.1 & 1.1 & 1.1 & 1.1 & 1.1 \\
\hline
\end{tabular}

Source: IMF's Direction of Trade Statistics (unless otherwise stated)

1) Taiwan's data comes from its Ministry of Finance. 
terms of their present well-being, three distinct groups of countries are easily identified: the richer city-states of Hong Kong and Singapore with income exceeding USD 20,000 per head, the maturing economies of Korea and Taiwan with per capita incomes of some USD 12,000-13,000, and the remaining economies with incomes of USD 4,000 or less per person.

Higher aggregate productivity normally requires sectoral shifts in the workforce during the growth process from low productivity agricultural or rural sectors to relatively high productivity, non-agricultural or urban sectors. In this regard, EEA's development process appears to have evolved according to international experience. The share of agriculture in aggregate output has declined and that of services has increased over time (Table 4). The share of services has risen in the higher per capita income countries of Hong Kong, Singapore, Korea and Taiwan, where it approaches percentages of around two thirds or higher. The manufacturing sector currently represents less than a quarter of the economies of Hong Kong, about one quarter of those of Korea, Taiwan, Philippines and Singapore, and a higher share in Malaysia, Thailand and China.

Table 3. Emerging East Asia per capita income ${ }^{1)}$ in USD, PPP-adjusted

\begin{tabular}{|c|c|c|c|c|c|c|}
\hline & \multicolumn{3}{|c|}{ current USD } & \multicolumn{3}{|c|}{$\begin{array}{c}\text { constant USD } \\
1995=100\end{array}$} \\
\hline & 1980 & 1990 & 2003 & 1980 & 1990 & 2002 \\
\hline China & 220 & 320 & 1100 & 708 & 1482 & 4054 \\
\hline Hong Kong & 5780 & 12520 & 25860 & 11068 & 18274 & 23833 \\
\hline Korea & 1760 & 5740 & 12030 & 4197 & 8389 & 15009 \\
\hline Taiwan ${ }^{2)}$ & 2345 & 8106 & 13162 & 3996 & 9151 & 11437 \\
\hline \multicolumn{7}{|l|}{ ASEAN-5 } \\
\hline Indonesia & 500 & 620 & 810 & 1346 & 2087 & 2857 \\
\hline Malaysia & 1830 & 2380 & 3880 & 3730 & 5079 & 8080 \\
\hline Philippines & 690 & 740 & 1080 & 3830 & 3574 & 3694 \\
\hline Singapore & 4830 & 11840 & 21230 & 8926 & 13435 & 21296 \\
\hline Thailand & 720 & 1520 & 2190 & 2291 & 4116 & 6208 \\
\hline
\end{tabular}

Sources: World Bank's World Development Indicators and Asian Development Bank's Key Indicators .

1) Unless otherwise indicated, per capita Gross National Income (GNI) estimated according to World Bank Atlas method of converting data in national currency to current US dollars. The Atlas method averages the exchange rate for a given year and the two preceding years, adjusted for differences in rates of inflation between the country and the G-5 countries (France, Germany, Japan, the United Kingdom, and the United States). The resulting total GNI estimate is then divided by the mid-year population to obtain per capita GNI.

2) Output data in USD is obtained by dividing current GNP in local currency by the corrresponding bilateral exchange rate. Deflated by US GDP deflator, rebased to $1995=100$ to obtain the constant USD series. 
Table 4. Emerging East Asia shares of major sectors in GDP ${ }^{1)}$ in $\%$

\begin{tabular}{|c|c|c|c|c|c|c|c|c|c|c|c|c|}
\hline & \multirow{2}{*}{\multicolumn{3}{|c|}{ Agriculture }} & \multicolumn{6}{|c|}{ Industry } & \multirow{2}{*}{\multicolumn{3}{|c|}{ Services }} \\
\hline & & & & & All & & Man & acturin & only & & & \\
\hline & 1980 & 1990 & 2003 & 1980 & 1990 & 2003 & 1980 & 1990 & 2003 & 1980 & 1990 & 2003 \\
\hline China & 30.1 & 27.0 & 14.6 & 48.5 & 41.6 & 52.3 & $44.2^{4)}$ & $37.0^{4)}$ & 45.3 & 21.4 & 31.3 & 33.1 \\
\hline Hong Kong ${ }^{2)}$ & 0.8 & 0.3 & 0.1 & 31.7 & 24.3 & 12.0 & 23.7 & 16.8 & 4.4 & 67.5 & 71.3 & 84.6 \\
\hline Korea & 14.9 & 8.5 & 3.2 & 41.3 & 43.1 & 34.6 & 29.7 & 28.8 & 23.4 & 43.7 & 48.4 & 62.2 \\
\hline Taiwan & 7.7 & 4.2 & 1.8 & 45.7 & 41.2 & 30.4 & 36.0 & 33.3 & 25.5 & 46.6 & 54.6 & 67.8 \\
\hline \multicolumn{13}{|l|}{ ASEAN-5 } \\
\hline Indonesia & 24.8 & 19.4 & 16.6 & 43.4 & 39.1 & 43.6 & 11.6 & 20.7 & 24.7 & 31.8 & 41.5 & 39.9 \\
\hline Malaysia & 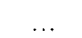 & 15.2 & 9.5 & $\ldots$ & 42.2 & 48.6 & & 24.2 & 31.2 & & 44.2 & 45.5 \\
\hline Philippines & 25.1 & 21.9 & 14.5 & 38.8 & 34.5 & 32.6 & 25.7 & 24.8 & 23.1 & 36.1 & 43.6 & 53.5 \\
\hline Singapore & 1.3 & 0.4 & 0.1 & 38.1 & 33.0 & 32.7 & 29.1 & 25.8 & 26.1 & 60.6 & 67.8 & 66.4 \\
\hline Thailand & 23.2 & 12.5 & 9.8 & 28.7 & 37.2 & 44.0 & 21.5 & 27.2 & 35.2 & 48.1 & 50.3 & 46.3 \\
\hline
\end{tabular}

Source: Asian Development Bank's Key Indicators.

1) Agriculture corresponds to ISIC divisions $1-5$ and includes forestry and fishing. Industry comprises value added in mining, manufacturing (also reported as a separate subgroup), construction, electricity, water, and gas (ISIC divisions 10-45), Manufacturing refers to industries belonging to divisions 15-37, Services correspond to ISIC divisions 50-99. Unless otherwise indicated, GDP data are at current market prices.

2) The latest observation refers to 2002 .

4) Includes mining and electricity, gas and water. 
The study of supply-side characteristics relating to the tradable sector includes country-specific commodity and geographical compositions of trade. These two types of trade compositions contribute to determine imported inflation in foreign currency $\left(\pi_{i}^{* e}+\varepsilon_{i}^{*}\right)$ and effective exchange rates $\left(s_{i}^{e}+\psi_{i}\right)$, as discussed in the Appendix (see expression (A.2)). As members of a currency union, countries still display imported inflation and effective exchange rates that are idiosyncratic, even if they face the same world prices and have both fixed bilateral rates among each other. Following our analysis of trade compositions, we compare the evolution of EEA countries' nominal and real effective exchange rates (NEER and REER, respectively). The insight from the model is that imported inflation is influenced by different commodity and geographical compositions of trade, thereby affecting effective exchange rates.

EEA countries exhibit some cross-country variation in their commodity composition of international trade (Tables 5 and 6). The largest SITC sector in terms of both imports and exports is in most cases machinery and transport equipment. Except for Chinese and Indonesian exports, in 2004 the shares of this category of goods ranged from roughly $30 \%$ to $60 \%$ of total imports, and $40 \%$ to $65 \%$ of total exports. ${ }^{13}$ Crosscountry discrepancies are also large in other sectors. The role of raw materials in total trade varies across EEA economies. China, Indonesia, and to a lesser extent Korea, Taiwan and Thailand exhibit large shares of imports of non-fuel crude materials. Korea and Indonesia stand out in the case of mineral fuel imports, their share exceeding the $20 \%$ mark in 2004 . Indonesia is the only raw materials producer with large export shares (mineral fuels and non-fuel materials explaining over one third of total sales abroad in 2004), followed by Malaysia and Singapore who each export more than $10 \%$ of the total in terms of mineral fuels. Finally, the share of trade in food has tended to be larger in the cases of some ASEAN-5 countries (such as Indonesia, the Philippines, and in the case of exports, Thailand).

Along the way, EEA has derived efficiency gains from the regionalization of production processes. ${ }^{14}$ As a result, the share of intra-regional trade has surged by some $10-20 \%$ for most economies (Table 7 ). These shares have also converged across countries, even if there still is some idiosyncratic variation. Hong Kong's and Malaysia's shares of intra-regional trade currently rank highest in the region, while most other countries exhibit shares of 30 to $40 \%$. Given that China has

\footnotetext{
${ }^{13}$ Lam et al. (2004) study the two sectors registering EEA's fastest export growth since 1990 (except for their "not elsewhere specified" items), namely, machinery and transport equipment, and chemicals.
} 
Table 5. Commodity composition of imports of Emerging East Asia economies as a percentage of each country's total imports, by SITC section, selected years

\begin{tabular}{|c|c|c|c|c|c|c|c|c|c|}
\hline \multicolumn{10}{|c|}{ A) 1995} \\
\hline & \multirow[b]{2}{*}{ China } & \multirow[b]{2}{*}{ Hong Kong } & \multirow[b]{2}{*}{ Korea } & \multirow[b]{2}{*}{ Taiwan } & \multicolumn{5}{|c|}{ ASEAN-5 } \\
\hline & & & & & Indonesia & Malaysia & Philippines & Singapore & Thailand \\
\hline Food and live animals & 4.6 & 3.9 & 4.4 & 3.6 & 7.4 & 4.1 & 7.4 & 2.9 & 2.9 \\
\hline Beverage and tobacco & 0.3 & 1.3 & 0.4 & 0.9 & 0.4 & 0.3 & 0.6 & 1.1 & 0.4 \\
\hline Crude materials excluding fuels & 7.7 & 2.2 & 8.7 & 6.3 & 9.0 & 2.4 & 4.3 & 1.2 & 5.4 \\
\hline Mineral fuels, etc. & 3.9 & 1.9 & 14.1 & 6.9 & 7.4 & 2.2 & 9.2 & 8.1 & 6.5 \\
\hline Animal, vegetable oil, and fats & 2.0 & 0.3 & 0.3 & 0.2 & 0.3 & 0.2 & 0.1 & 0.4 & 0.1 \\
\hline Chemicals & 13.1 & 7.5 & 9.7 & 13.3 & 15.4 & 7.1 & 9.2 & 6.5 & 10.1 \\
\hline Basic manufactures & 21.8 & 20.5 & 15.7 & 17.8 & 16.4 & 13.9 & 13.9 & 10.9 & 20.6 \\
\hline Machines, transport equipment & 6.3 & 37.1 & 36.6 & 40.2 & 40.1 & 60.1 & 32.5 & 57.9 & 49.0 \\
\hline Miscellaneous manufactured goods & 39.8 & 25.0 & 8.0 & 7.6 & 3.5 & 4.9 & 3.5 & 9.9 & 2.6 \\
\hline Unclassified goods & 0.5 & 0.3 & 2.1 & 3.2 & 0.1 & 4.9 & 19.2 & 1.2 & 2.4 \\
\hline Total & 100.0 & 100.0 & 100.0 & 100.0 & 100.0 & 100.0 & 100.0 & 100.0 & 100.0 \\
\hline
\end{tabular}

\begin{tabular}{|c|c|c|c|c|c|c|c|c|c|}
\hline & \multirow[b]{2}{*}{ China } & \multirow[b]{2}{*}{ Hong Kong } & \multirow[b]{2}{*}{ Korea } & \multirow[b]{2}{*}{ Taiwan } & \multicolumn{5}{|c|}{ ASEAN-5 } \\
\hline & & & & & Indonesia & Malaysia & Philippines & Singapore & Thailand \\
\hline Food and live animals & 1.6 & 2.6 & 4.1 & 2.5 & 8.4 & 4.2 & 5.9 & 2.1 & 3.0 \\
\hline Beverage and tobacco & 0.1 & 0.5 & 0.2 & 0.6 & 0.4 & 0.3 & 0.6 & 0.7 & 0.3 \\
\hline Crude materials excluding fuels & 9.9 & 1.1 & 6.0 & 4.2 & 8.2 & 2.6 & 2.5 & 0.5 & 4.3 \\
\hline Mineral fuels, etc. & 8.6 & 2.4 & 22.4 & 12.4 & 24.4 & 6.3 & 11.7 & 15.0 & 14.0 \\
\hline Animal, vegetable oil, and fats & 0.8 & 0.1 & 0.2 & 0.1 & 0.2 & 0.7 & 0.3 & 0.2 & 0.1 \\
\hline Chemicals & 11.7 & 6.1 & 9.2 & 12.3 & 16.5 & 8.0 & 7.9 & 6.5 & 10.5 \\
\hline Basic manufactures & 13.2 & 15.5 & 13.7 & 13.5 & 13.6 & 11.0 & 8.7 & 6.7 & 20.0 \\
\hline Machines, transport equipment & 8.9 & 50.8 & 33.6 & 42.6 & 25.7 & 57.7 & 38.1 & 58.7 & 42.0 \\
\hline Miscellaneous manufactured goods & 45.0 & 20.9 & 8.8 & 10.5 & 2.5 & 5.9 & 3.4 & 8.6 & 2.7 \\
\hline Unclassified goods & 0.3 & 0.1 & 1.6 & 1.4 & 0.0 & 3.1 & 21.1 & 1.1 & 3.1 \\
\hline Total & 100.0 & 100.0 & 100.0 & 100.0 & 100.0 & 100.0 & 100.0 & 100.0 & 100.0 \\
\hline
\end{tabular}

Sources: National sources for trade statistics. 
Table 6. Commodity composition of exports of Emerging East Asia economies

as a percentage of each country's total exports, by SITC section, selected years

\begin{tabular}{|c|c|c|c|c|c|c|c|c|c|}
\hline & \multirow[b]{2}{*}{ China } & \multirow[b]{2}{*}{ Hong Kong } & \multirow[b]{2}{*}{ Korea } & \multirow[b]{2}{*}{ Taiwan } & \multicolumn{5}{|c|}{ ASEAN-5 } \\
\hline & & & & & Indonesia & Malaysia & Philippines & Singapore & Thailand \\
\hline Food and live animals & 6.7 & 1.6 & 2.1 & 3.4 & 7.9 & 2.4 & 7.7 & 2.1 & 19.1 \\
\hline Beverage and tobacco & 0.9 & 1.2 & 0.1 & 0.1 & 0.4 & 0.2 & 0.2 & 1.4 & 0.3 \\
\hline Crude materials excluding fuels & 2.9 & 1.8 & 1.4 & 1.8 & 11.1 & 6.5 & 3.0 & 1.4 & 5.8 \\
\hline Mineral fuels, etc. & 3.6 & 1.0 & 2.0 & 0.7 & 25.3 & 7.0 & 1.5 & 8.3 & 0.6 \\
\hline Animal, vegetable oil, and fats & 0.3 & 0.2 & 0.0 & 0.0 & 3.0 & 6.8 & 4.8 & 0.4 & 0.0 \\
\hline Chemicals & 6.1 & 6.2 & 7.1 & 6.8 & 3.4 & 3.0 & 2.0 & 6.0 & 3.1 \\
\hline Basic manufactures & 21.7 & 16.6 & 21.7 & 23.2 & 23.0 & 8.8 & 6.4 & 6.3 & 18.1 \\
\hline Machines, transport equipment & 0.7 & 32.4 & 52.9 & 48.1 & 8.4 & 55.2 & 22.2 & 65.7 & 33.9 \\
\hline Miscellaneous manufactured goods & 57.1 & 38.5 & 10.5 & 15.9 & 17.3 & 8.7 & 12.9 & 7.5 & 18.2 \\
\hline Unclassified goods & 0.0 & 0.6 & 2.1 & 0.1 & 0.1 & 1.3 & 39.3 & 0.9 & 0.9 \\
\hline Total & 100.0 & 100.0 & 100.0 & 100.0 & 100.0 & 100.0 & 100.0 & 100.0 & 100.0 \\
\hline
\end{tabular}

\begin{tabular}{|c|c|c|c|c|c|c|c|c|c|}
\hline & \multirow[b]{2}{*}{ China } & \multirow[b]{2}{*}{ Hong Kong } & \multirow[b]{2}{*}{ Korea } & \multirow[b]{2}{*}{ Taiwan } & \multicolumn{5}{|c|}{ ASEAN-5 } \\
\hline & & & & & Indonesia & Malaysia & Philippines & Singapore & Thailand \\
\hline Food and live animals & 3.2 & 0.6 & 1.0 & 1.2 & 5.4 & 2.1 & 4.2 & 1.1 & 12.4 \\
\hline Beverage and tobacco & 0.2 & 0.3 & 0.2 & 0.0 & 0.4 & 0.3 & 0.3 & 0.6 & 0.2 \\
\hline Crude materials excluding fuels & 1.0 & 1.0 & 1.0 & 1.4 & 8.4 & 2.6 & 1.1 & 0.6 & 5.1 \\
\hline Mineral fuels, etc. & 2.4 & 0.2 & 4.2 & 3.1 & 26.2 & 11.7 & 1.4 & 12.2 & 3.2 \\
\hline Animal, vegetable oil, and fats & 0.0 & 0.0 & 0.0 & 0.0 & 6.2 & 5.6 & 1.5 & 0.1 & 0.2 \\
\hline Chemicals & 4.4 & 5.0 & 9.3 & 9.3 & 5.5 & 5.7 & 1.1 & 11.7 & 6.8 \\
\hline Basic manufactures & 17.0 & 13.0 & 14.7 & 18.4 & 18.2 & 7.8 & 3.2 & 3.7 & 16.3 \\
\hline Machines, transport equipment & 0.8 & 50.1 & 62.9 & 52.4 & 15.9 & 54.2 & 42.3 & 61.1 & 45.4 \\
\hline Miscellaneous manufactured goods & 71.0 & 29.6 & 5.8 & 13.8 & 13.6 & 8.5 & 6.7 & 7.9 & 8.7 \\
\hline Unclassified goods & 0.0 & 0.1 & 1.0 & 0.3 & 0.4 & 1.5 & 38.2 & 1.0 & 1.6 \\
\hline Total & 100.0 & 100.0 & 100.0 & 100.0 & 100.0 & 100.0 & 100.0 & 100.0 & 100.0 \\
\hline
\end{tabular}

Sources: National sources for trade statistics.

1) Data for the Phillipines is for 2003. 
played an important role in driving intra-regional trade, from the perspective of the creation of a currency union it would matter whether this country is in the union or not. $^{15}$

With regard to extra-regional trade, the shares of Japan, US and euro area in total trade of each EEA country's trade are currently similar to those observed in 1990 (Table 7). Among the largest changes over the period, Korean trade with Japan lost ground to both trade with the US and intra-regional transactions, while Indonesian trade with Japan was to some extent replaced with intra-regional sales. In 2003, EEA's trade with Japan, the US and the euro area was rather evenly split among these three areas. From a monetary union standpoint, convergence in EEA countries' shares of extra-regional trade would help better deal with large fluctuations in the value of major currencies. ${ }^{16}$

The evolution of NEER and REER indicates that EEA countries' effective exchange rates have displayed considerable cross-country variability over time (Tables 8 and 9). This is the case even if we take out periods over which exchange rate behaviour was shaped by country-specific changes (such as China's decision to abandon its dual exchange rate regime in 1994) or when currencies were both widely and intensely affected such as in the Asian crisis of 1997-98. REER movements are revealing about the trend of EEA's competitiveness over the past fifteen years. In comparison with 1990, all of EEA's currencies have lost real value with the exception of Hong Kong, which has appreciated in real terms, and Singapore, whose REER is roughly unchanged (Table 9). The extent of the real depreciation varies across countries, ranging from $10 \%$ to $25 \%$. The weakening of the

\footnotetext{
${ }^{14}$ EEA's diverse pool of countries in terms of their stage in the development process allows for labourintensive downstream stages of the production process to be shifted to lower wage countries such as China, while more mature industrial economies such as Korea and Taiwan specialise in exports of higher value-added machinery and components. This has fostered the competitiveness of regional products as a whole via economies of scale and a better organisation of the production process.
${ }^{15}$ One limitation of standard analyses of trade is that there is no comprehensive data distinguishing between trade induced by EEA economies' domestic demand and other sources of trade. The latter include processing trade aiming at third countries or even transactions of merchandise in transit - the latter playing an important role in the cases of Hong Kong and Singapore. Rumbaugh and Blancher (2004) estimate China's export re-processing to be half of the country's total trade.

${ }^{16}$ McKinnon and Schnabl (2003) study the role of the yen/US dollar rate in EEA, finding that major yen devaluations adversely affect the region's economic activity. Kang et al. (2005) qualify this conclusion by showing that the effects of the weakening of the yen against the US dollar exchange rate on the Korean economy are statistically significant only since the Asian crisis.
} 
Table 7. Bilateral trade of Emerging East Asia economies ${ }^{1)}$ as a percentage of each country's total trade, selected years

\begin{tabular}{|c|c|c|c|c|c|c|c|c|c|c|c|c|}
\hline \multicolumn{13}{|l|}{ A) 1990} \\
\hline & \multirow[b]{2}{*}{ China } & \multirow[b]{2}{*}{ Hong Kong } & \multirow[b]{2}{*}{ Korea } & \multicolumn{5}{|c|}{ ASEAN-5 } & \multirow{2}{*}{\begin{tabular}{|c|} 
Subtotal \\
Emerging Asia
\end{tabular}} & \multirow[b]{2}{*}{ Japan } & \multirow[b]{2}{*}{ US } & \multirow[b]{2}{*}{ Euro area } \\
\hline & & & & Indonesia & Malaysia & Philippines & Singapore & Thailand & & & & \\
\hline \multirow{2}{*}{\begin{tabular}{|l|} 
China \\
Hong Kong
\end{tabular}} & & 39.6 & 0.6 & 1.2 & 1.0 & 0.2 & 2.5 & 1.1 & 46.2 & 15.0 & 14.2 & 13.8 \\
\hline & 28.1 & & 0.5 & 3.0 & 0.7 & 0.9 & 0.6 & 3.4 & 1.1 & 38.3 & 10.1 & 13.1 \\
\hline \multirow{2}{*}{$\begin{array}{l}\text { Korea } \\
\text { ASEAN-5 }\end{array}$} & 0.5 & 3.5 & & 1.1 & 1.5 & 0.5 & 2.0 & 1.0 & 10.1 & 21.3 & 24.6 & 9.6 \\
\hline & & & & & & & & & & & & \\
\hline Indonesia & 2.9 & 2.3 & 3.2 & & 1.3 & 0.3 & 4.9 & 1.0 & 16.0 & 21.1 & 12.0 & 13.4 \\
\hline Malaysia & 2.1 & 2.7 & 3.8 & 1.1 & & 0.8 & 22.4 & 2.9 & 35.6 & 19.2 & 16.1 & 10.6 \\
\hline Philippines & 1.3 & 5.0 & 3.5 & 0.7 & 2.3 & & 4.1 & 1.4 & 18.2 & 20.5 & 27.7 & 11.5 \\
\hline Singapore & 2.5 & 5.0 & 2.5 & 2.1 & 11.5 & 0.8 & & 4.1 & 28.4 & 13.7 & 17.2 & 10.2 \\
\hline Thailand & 2.3 & 3.2 & 2.5 & 0.9 & 3.0 & 0.5 & 8.3 & & 20.7 & 24.3 & 15.4 & 14.7 \\
\hline
\end{tabular}

\begin{tabular}{|c|c|c|c|c|c|c|c|c|c|c|c|c|}
\hline \multicolumn{13}{|c|}{ ASEAN-5 } \\
\hline & China & Hong Kong & Korea & Indonesia & Malaysia & Philippines & Singapore & Thailand & $\begin{array}{c}\text { Subtotal } \\
\text { Emerging Asia }\end{array}$ & Japan & US & Euro area \\
\hline China & & 16.7 & 7.1 & 1.0 & 2.0 & 0.8 & 2.4 & 1.4 & 31.4 & 15.7 & 18.7 & 14.3 \\
\hline Hong Kong & 31.1 & & 3.6 & 0.4 & 1.8 & 1.2 & 3.7 & 1.3 & 43.2 & 7.8 & 8.5 & 6.1 \\
\hline Korea & 16.2 & 4.5 & & 1.3 & 2.1 & 1.2 & 2.7 & 1.2 & 29.1 & 14.3 & 16.4 & 10.3 \\
\hline ASEAN-5 & & & & & & & & & & & & \\
\hline Indonesia & 9.1 & 2.1 & 5.3 & & 3.6 & 0.8 & 7.5 & 2.5 & 30.9 & 12.0 & 12.2 & 12.2 \\
\hline Malaysia & 9.1 & 4.5 & 4.2 & 1.8 & & 2.2 & 18.8 & 4.5 & 45.1 & 13.1 & 18.8 & 10.8 \\
\hline Philippines & 9.0 & 7.2 & 5.9 & 1.0 & 5.7 & & 7.5 & 3.8 & 40.1 & 20.0 & 22.5 & 11.7 \\
\hline Singapore & 7.5 & 6.2 & 3.6 & 2.6 & 13.0 & 2.0 & & 3.8 & 38.7 & 8.3 & 13.0 & 9.8 \\
\hline Thailand & 7.8 & 3.8 & 2.9 & 1.5 & 5.4 & 1.8 & 6.7 & & 29.8 & 18.4 & 13.7 & 9.7 \\
\hline
\end{tabular}

Source: IMF's Direction of Trade Statistics.

${ }^{1)}$ No comparable data is available for Taiwan. 
Table 8. Emerging East Asia nominal effective exchange rates ${ }^{1)}$

$1990=100$

\begin{tabular}{|c|c|c|c|c|c|c|c|c|c|c|c|c|c|c|c|}
\hline & 1990 & 1991 & 1992 & 1993 & 1994 & 1995 & 1996 & 1997 & 1998 & 1999 & 2000 & 2001 & 2002 & 2003 & 2004 \\
\hline China & 100.0 & 90.5 & 80.1 & 64.3 & 58.2 & 57.5 & 60.0 & 63.9 & 66.8 & 65.4 & 67.2 & 70.2 & 69.6 & 64.8 & 61.8 \\
\hline Hong Kong & 100.0 & 99.5 & 97.2 & 99.3 & 96.7 & 91.5 & 95.6 & 102.7 & 109.4 & 106.1 & 108.9 & 115.1 & 113.6 & 104.8 & 98.7 \\
\hline Korea & 100.0 & 94.8 & 86.3 & 83.6 & 80.7 & 79.9 & 80.8 & 74.6 & 52.3 & 59.0 & 63.4 & 58.7 & 60.4 & 58.5 & 57.5 \\
\hline $\begin{array}{l}\text { Taiwan } \\
\text { ASEAN-5 }\end{array}$ & 100.0 & 98.8 & 102.7 & 97.7 & 94.4 & 89.5 & 90.5 & 92.7 & 83.4 & 83.6 & 88.2 & 86.0 & 83.6 & 77.8 & 76.0 \\
\hline Mala & 100.0 & 99.2 & 107.1 & 111.1 & 110.3 & 110.3 & 113.7 & 110.6 & 85 & 86 & 88.2 & 93.3 & 92 & 86.5 & 82.3 \\
\hline Philippines & 100.0 & 88.0 & 94.8 & 89.3 & 91.7 & 93.9 & 92.2 & 83.3 & 59.2 & 61.9 & 55.0 & 47.4 & 46.9 & 44.6 & 43.1 \\
\hline Singapore & 100.0 & 103.9 & 107.3 & 109.2 & 112.4 & 114.8 & 121.2 & 123.7 & 116.3 & 110.7 & 111.4 & 113.4 & 112.4 & 106.7 & 104.0 \\
\hline Thailand & 100.0 & 101.4 & 100.2 & 102.0 & 104.8 & 102.1 & 104.3 & 93.0 & 76.9 & 80.9 & 78.1 & 74.2 & 76.1 & 74.2 & 73.5 \\
\hline
\end{tabular}

Sources: BIS and IMF's International Financial Statistics.

1) An increase (decrease) in the value of this variable implies a nominal exchange rate appreciation (depreciation).

${ }^{2)}$ No data is available for Indonesia.

Table 9. Emerging East Asia real effective exchange rates ${ }^{1)}$

1990-100

\begin{tabular}{|c|c|c|c|c|c|c|c|c|c|c|c|c|c|c|c|}
\hline & 1990 & 1991 & 1992 & 1993 & 1994 & 1995 & 1996 & 1997 & 1998 & 1999 & 2000 & 2001 & 2002 & 2003 & 2004 \\
\hline China & 100.0 & 91.0 & 90.4 & 105.0 & 75.8 & 79.6 & 84.5 & 90.3 & 95.1 & 89.8 & 92.2 & 96.8 & 94.5 & 90.0 & 88.7 \\
\hline Hong Kong & 100.0 & 106.3 & 109.9 & 118.6 & 121.6 & 122.9 & 133.8 & 149.1 & 160.8 & 148.4 & 144.0 & 147.4 & 139.8 & 123.9 & 114.7 \\
\hline Korea & 100.0 & 99.5 & 93.5 & 92.5 & 93.1 & 94.7 & 98.7 & 93.0 & 69.4 & 78.3 & 84.7 & 80.5 & 84.4 & 83.8 & 84.2 \\
\hline Taiwan & 100.0 & 98.8 & 102.7 & 97.7 & 94.4 & 89.5 & 90.5 & 92.7 & 83.4 & 83.6 & 88.2 & 86.0 & 83.6 & 77.8 & 76.0 \\
\hline ASEAN-5 & & & & & & & & & & & & & & & \\
\hline Indonesia ${ }^{2)}$ & 100.0 & 100.6 & 99.2 & 101.1 & 99.9 & 98.3 & 101.6 & 94.4 & 47.6 & 72.6 & 70.0 & 67.4 & 81.2 & 86.0 & 79.8 \\
\hline Malaysia & 100.0 & 97.7 & 104.4 & 105.5 & 101.4 & 101.7 & 106.2 & 105.0 & 83.4 & 85.8 & 88.0 & 92.8 & 92.9 & 85.4 & 80.5 \\
\hline Philippines & 100.0 & 97.0 & 105.6 & 97.3 & 104.0 & 102.6 & 113.5 & 106.7 & 84.7 & 90.3 & 87.7 & 94.2 & 97.9 & 93.9 & 88.6 \\
\hline Singapore & 100.0 & 102.8 & 105.1 & 106.3 & 110.2 & 112.2 & 117.6 & 119.9 & 110.6 & 105.0 & 105.6 & 107.0 & 104.7 & 98.6 & 96.2 \\
\hline Thailand & 100.0 & 101.8 & 100.3 & 101.2 & 104.1 & 102.7 & 107.2 & 98.0 & 85.3 & 88.7 & 85.7 & 81.3 & 82.9 & 81.2 & 80.9 \\
\hline
\end{tabular}

Sources: BIS and IMF's International Financial Statistics (unless otherwise stated)

1) An increase (decrease) in the value of this variable implies a real exchange rate appreciation (depreciation)

2) Data for Indonesia comes from JP Morgan. 
currencies was already evident in non-ASEAN-5 countries in the mid-1990s, a time in which China unified its exchange rates. The magnitude of these real depreciations increased during and after the period of the Asian financial crisis in 1997-98. However, also countries that did not experience significant nominal depreciations during the Asian financial crisis faced some sizeable real depreciations over the past fifteen years, foremost China with a $11.3 \%$ REER depreciation since 1990.

Finally, another factor influencing supply parameter $\alpha_{i}$ is the degree of openness of an economy, as shown in the Appendix. One way to quickly assess large crosscountry discrepancies in openness is by comparing the shares of each country in world GDP and exports (Tables 1 and 2). ${ }^{17}$ We do observe marked differences between the shares in world GDP and exports in some countries, with the city states of Hong Kong and Singapore standing out as the most open economies in the region.

In sum, EEA economies appear to have rather diverse supply characteristics. The region displays significant cross-country variation in the stage of development, the shares of different sectors in the economy, size, and the degree of openness. EEA countries constitute a rather diverse pool in terms of commodity compositions of trade, while there has been some convergence in terms of their geographical compositions of trade. The former is a negative factor contributing to create nominal divergence via differential imported inflation. Despite geographical convergence in trade patterns across EEA, cross-country variability in the region's effective exchange rates is considerable.

\section{B. Correlation of shocks}

This subsection goes beyond the previous focus on supply by reviewing the evidence on the correlation of a wide variety of shocks. The related literature on EEA goes back to Bayoumi and Eichengreen (1994), who use a sample of 9 East Asian countries over the period 1969-89, alongside 15 EU countries over 1963-90. They break down unexpected macro developments into demand and supply shocks à la Blanchard and Quah (1989), finding that there is little difference in the asymmetry of both shocks between Europe and East Asia. They detect high correlation of shocks particularly among some of the pairs involving Japan, Korea, Taiwan Hong

\footnotetext{
${ }^{17}$ The reason why we emphasise "large" is that shares in world GDP are PPP-adjusted while those in world exports are not, which can prevent too precise comparisons between them.
} 
Kong, Indonesia, Malaysia and Singapore. ${ }^{18}$ Eichengreen and Bayoumi (1999) complement Bayoumi and Eichengreen's (1994) analysis by employing an optimal currency area (OCA) index. ${ }^{19}$ Some pairs of countries in East Asia are found to be somewhat plausible candidates for a monetary union as the members of the EU. These pairs are: Singapore-Malaysia, Singapore-Thailand, Singapore-Hong Kong, Singapore-Taiwan and Hong Kong-Taiwan. Other pairs, those including Indonesia, South Korea and the Philippines, do not rank high, while the Malaysia-Thailand pair displays a very weak score. Bayoumi and Mauro (1999) update Bayoumi and Eichengreen's (1994) study using data for 11 East Asian countries over 1968-98 as well as the same 15 EU member states over 1969-89. Shocks are highly correlated among Hong Kong, Indonesia, Malaysia, Singapore, that is, a smaller club of East Asian countries than in the original study. Focusing on ASEAN economies, the authors conclude that, while they are less suited for a regional currency arrangement than Europe, the difference is not large. ${ }^{20}$ Baek and Song (2002) cover a larger group of 14 East-Asian economies over the period 1970-1999. They identify a group of six countries (Hong Kong, Indonesia, Japan, Korea, Malaysia and Thailand) experiencing symmetric supply disturbances. Singapore and Taiwan share similar demand disturbances with this group, while China's economic disturbances are small in size and quickly absorbed. Thus, they claim that these nine countries are viable candidates for a currency union (EA9). Compared with the Europe prior to 1990, the EA9 economies show larger disturbances but faster adjustment speeds. With small disturbances and rapid adjustments, China is close to the European anchor country, Germany.

Clavel et al. (2005) deviate from Blanchard and Quah's identification approach. ${ }^{21}$ They use sign-restricted VAR models for the 10 largest emerging Asian countries over 1979-2003. They relate three types of domestic shocks (supply, real demand and monetary) across the region in terms of correlation and principal component analysis. In some cases, some degree of co-movement between pairs of

\footnotetext{
${ }^{18}$ The authors also report a relatively fast speed of adjustment to shocks in EEA. Almost all of the responses in output and prices take place in the first two years, compared with at most half in Europe. This is consistent with the notion that EEA labour markets are relatively flexible.
${ }^{19}$ The OCA index is based on a regression where the LHS variable is the standard deviation of the change in the logarithm of the end-year bilateral exchange rate between any two countries. The RHS variables measure the sectoral diversity of trade, the degree of openness, and size. The countries considered are Japan and its 19 leading trading partners over the period 1976-1995.

${ }^{20}$ They also confirm EEA's relatively fast speed of adjustment.
} 
individual countries' shocks is found, but by and large intra-regional factors do not appear to be particularly important. The results indicate that economic developments in emerging Asia are largely driven by country-specific shocks, whereas regionalization seems to be of only limited importance. Taken altogether, these findings are consistent with the dynamic factor decomposition results of Kose et al. (2003). The latter find that, in both Asia and Latin America, macroeconomic fluctuations are largely explained by domestic factors, while extra-regional and especially intra-regional developments play a much more modest role.

Finally, Girardin (2005) examines the similarities of GDP growth-cycle features of 10 East Asian countries over 1978-2002. He computes contemporaneous correlations of smoothed probabilities of two regimes, namely, the growth-recession and rapid growth regimes between China or Japan and other East Asian economies. For the overall period, growth-recessions in China or Japan are substantially correlated both with Indonesia and Thailand, while Hong Kong, South Korea and Malaysia also correlate with China, and Singapore and Taiwan with Japan. In Girardin's subsample results for the 1990s, all countries, except Taiwan, are correlated with the two North East Asian economies, but in almost all cases correlations with China are much larger than with Japan. The degree of correlation of most East Asian countries with China is comparable to that found in Europe over 1970-1996. Overall, on the basis of the experience of the 1990s with growth-cycle synchronization, Girardin concludes that China is a better candidate for monetary integration with East Asian countries than Japan, but not yet a perfect candidate.

The papers reviewed in this subsection are not strictly comparable. They constitute a heterogeneous whole in terms of objectives, methodologies and samples. Our review of this literature indicates that the evidence produced is not very clear, with different analyzes pointing to different groups of plausible partners for monetary cooperation (or no such group at all) based on the similarity of various shocks and sometimes the speed of adjustment. One tentative conclusion that, at present, we can draw from this diverse pool of studies is that there is not very compelling evidence that shocks are highly correlated across the region. The analysis of shock correlations among EEA countries remains a fruitful area for further research.

\footnotetext{
${ }^{21}$ They make the observation that Blanchard and Quah's approach is subject to a small-sample bias, as found by Faust and Leeper (1997).
} 


\section{Inflation targets}

Inflation targets are treated in our model as parameters that enter welfare considerations. Higher levels of inflation targets have, ceteris paribus, a more adverse effect on stabilization properties the larger the country is. Our analysis focuses on those middle-income countries in the region that have recently adopted inflation targeting (IT). Such decisions were made by Korea in 1998, Indonesia in 2000, Thailand in 2000, and the Philippines in 2001. Inflation rates have declined to some extent relative to the crisis and pre-crisis periods in Korea, Thailand and the Philippines. Thailand, Korea and the Philippines have tended to be within target, although Korea surpassed its 2001 and 2002 targets and the Philippines undershot its targets in 2002 and 2003, and overshot it in 2004 (Table 10). Indonesia has in the meantime experienced difficulties keeping its inflation within its target range.

In sum, EEA larger inflation targeters have showed lower desired inflation than the smaller ones. This configuration contributes positively to stabilization performance of a currency union, as previously analyzed. However, the smaller economies of Indonesia and the Philippines exhibit relatively high inflation targets by international standards, implying that running a currency union including them would entail welfare losses for monetary policy. This is a directly important matter if one considers ASEAN monetary integration, while it requires to be put in a broader context when it comes to monetary integration for the entire EEA region.

\section{Conclusions}

This paper proposes a simple analytical framework for the study of currency unions of small open economies, with a focus on the conduct of monetary policy in the presence of different types of shocks. Model results are then used to empirically assess the prospects for monetary integration between emerging East Asian economies. Our empirical investigation looks at a number of characteristics of emerging East Asian countries that helps us gauge supply-side diversity. Moreover, we discuss the evidence on the cross-country variation of disturbances hitting the region, as well as recent data on inflation targets. Overall, our analysis shows that these economies display rather diverse supply characteristics, the evidence that shocks are highly correlated across the region is not very compelling and some countries declare relatively high desired levels of inflation. A better factual understanding of welfare 
Table 10. Actual versus targeted inflation rates in Emerging East Asia1) in percent per annum, selected countries

\begin{tabular}{|c|c|c|c|c|c|c|c|c|c|c|c|c|c|c|}
\hline & \multicolumn{2}{|c|}{1999} & \multicolumn{2}{|c|}{2000} & \multicolumn{2}{|c|}{2001} & \multicolumn{2}{|c|}{2002} & \multicolumn{2}{|c|}{2003} & \multicolumn{2}{|c|}{2004} & \multicolumn{2}{|c|}{2005} \\
\hline & Target & Actual & Target & Actual & Target & Actual & Target & Actual & Target & Actual & Target & Actual & Target & Actual \\
\hline Korea & 3.0 & 0.8 & 2.5 & 1.8 & 2.5 & $3.6(3.2)$ & 2.5 & $3.7(3.1)$ & 2.5 & $3.4(2.8)$ & $2.5-3.5$ & $3.0(2.9)$ & $2.5-3.5$ & \\
\hline Indonesia & & & $3-5$ & 9.4 & $3-5$ & 12.5 & $3-5$ & 10.0 & $8-10$ & 5.1 & $4.5-5.5$ & 6.4 & $5-7$ & \\
\hline Thailand & & & $0-3.5$ & $1.4(0.8)$ & $0-3.5$ & $0.8(1.2)$ & $0-3.5$ & $0.7(0.4)$ & $0-3.5$ & $1.8(0.2)$ & $0-3.5$ & $2.7(0.4)$ & $0-3.5$ & \\
\hline Philippines & & & & & $6-7$ & 6.1 & $4.5-5.5$ & 3.1 & $4.5-5.5$ & $3.5(3.4)$ & 5 & $6.0(5.7)$ & 5 & \\
\hline
\end{tabular}

Sources: Bank of Korea, Bank Indonesia, Bank of Thailand, and Bangko Sentral ng Pilipinas websites

1) Headline CPI inflation, with core inflation rates between parentheses in countries reporting the latter measure. 
implications of monetary integration in the region would benefit from future empirical work concerning estimation of structural parameters for the region's economies as well as further investigation of the cross-country properties of disturbances. The present paper does not assess other important aspects that have attracted interest in the literature on monetary integration in East Asia, such as: i) the current state of institutional development concerning economic and in particular financial regional integration; ii) financial market integration in the region (constrained by the presence of capital controls and insulated banking sectors in some countries); and iii) the lack of strong political will to push the regional integration efforts forward (see Eichengreen and Bayoumi, 1999, Kwack, 2005, Williamson, 2002, Wyplosz, 2002).

The analysis presented here may help explain why the major issue for monetary integration in East Asia at present is not a formation of a currency union, but rather monetary coordination under a variety of forms. Having said this, it is important to bear in mind that integration via trade, financial and financial flows go hand in hand with each other. For this reason, increasing trade, financial and investment interdependence could reinforce each other over time, leading to a different conclusion regarding the degree of maturity of the conditions for deeper economic integration and in particular a monetary union. In addition, further progress in real and monetary integration may prove instrumental in shaping ongoing developments in the sphere of domestic policies (including monetary and exchange rate policies) and regional financial cooperation efforts.

\section{Acknowledgements}

This paper was prepared for the Workshop "Globalisation and Regionalism: Implications for Europe" organized by the European Central Bank (ECB). This is a shortened version of the ECB Working Paper of the same title. Comments from Daniel Heymann are gratefully acknowledged. The views expressed here do not necessarily reflect those of the ECB. The usual disclaimer applies.

Received 12 December 2005, Accepted 28 June 2006

\section{Appendix: Derivation of aggregate supply schedule}

Here we derive aggregate supply schedule (1) from assumptions about changes in the prices of domestic goods and imports. Deviations of non-tradable inflation, 
$\pi_{i}^{N}$, from its expected value are driven by aggregate output and a domestic supply shock, $\varepsilon_{i}^{N}$ :

$$
\pi_{i}^{N}=\pi_{i}^{N^{e}}+\lambda_{i} y_{i}+\varepsilon_{i}^{N}
$$

Tradable inflation, $\pi_{i}^{T}$, is the sum of two parts: i) expected plus unexpected foreign inflation, $\left(\pi_{i}^{*_{e}}+\varepsilon_{i}^{*}\right)$, and ii) expected plus unexpected NEER depreciation, $\left(s_{i}^{e}+\psi_{i}\right) .^{22}$

$$
\pi_{i}^{T}=\left(\pi_{i}^{* e}+\varepsilon_{i}^{*}\right)+\left(s_{i}^{e}+\psi_{i}\right)
$$

Using (A.1) and (A.2), we derive equation (1), with country $i^{\prime}$ 's overall actual and expected inflation being defined as $\pi_{i} \equiv\left(1-\gamma_{i}\right) \pi_{i}^{N}+\gamma_{i} \pi_{i}^{T}$ and $\pi_{i}^{e} \equiv\left(1-\gamma_{i}\right) \pi_{i}^{N^{e}}$ $+\gamma_{i}\left(\pi_{i}^{* e}+s_{i}^{e}\right)$, respectively. Parameter $\gamma_{i}$ reflects the weight of non-tradables in the economy. In (1), coefficient $\alpha_{i}$ equals $1 /\left[\left(1-\gamma_{i}\right) \lambda_{i}\right]$, while aggregate supply shock $\varepsilon_{i}$ can be decomposed into its domestic and external determinants as follows:

$$
\varepsilon_{i}=-\frac{\varepsilon_{i}^{N}}{\lambda_{i}}-\frac{\gamma_{i}}{\left(1-\gamma_{i}\right) \lambda_{i}}\left(\varepsilon_{i}^{*}+\psi_{i}\right)
$$

The first term in (A.3) captures unexpected non-tradable inflation. The second term is a composite shock to tradable inflation driven by randomness in either tradable prices in foreign currency or nominal effective exchange rates. The latter two developments can in turn be traced back to country-specific commodity compositions of international trade and idiosyncratic weights attached to different trading partners, respectively. ${ }^{23}$

\section{References}

Alesina, A., Barro, R. (2002) Currency unions, Quarterly Journal of Economics, 117, 409436.

\footnotetext{
${ }^{22}$ All error terms in (A.1) and (A.2) are assumed to be white noise with constant variance.

${ }^{23}$ Supply shock 's $\varepsilon_{i}^{\prime}$ components might be correlated with each other. For instance, shocks to foreign prices as captured by $\varepsilon_{i}^{*}$ could be correlated with shocks to effective exchange rate shocks in $\psi_{i}$. In this regard, for advanced economies, Jiménez-Rodríguez and Sánchez (2005) show that oil shocks induce a real exchange rate appreciation in some countries (US and Germany) while inducing a real exchange rate depreciation in others (such as other euro area countries and Japan).
} 
Alesina, A., Barro, R., Tenreyro, S. (2002) Optimal currency areas, NBER Working Paper No. 9072.

Baek, S.-G., Song, C.-Y. (2002) Is currency union a feasible option in East Asia?, in Currency union in East Asia. Edited by Choo, H.-G., Wang, Y., Korea Institute for International Economic Policy, Seoul, 107-146.

Bayoumi, T., Eichengreen, B. (1994) One money or many? Analyzing the prospects for monetary unification in various parts of the world, Princeton Studies in International Finance No. 76.

Bayoumi, T., Mauro, P. (1999) The suitability of ASEAN for a regional currency arrangement, IMF Working Paper No. 162.

Blanchard, O., Quah, D. (1989) The dynamic effect of aggregate demand and supply disturbances, American Economic Review, 79, 655-673.

Buiter, W., Corsetti, G., Pesenti, P. (1998a) Financial markets and European monetary cooperation: The lessons of the 1992--93 exchange rate mechanism crisis, Cambridge University Press, Cambridge.

Buiter, W., Corsetti, G., Pesenti, P. (1998b) Interpreting the ERM crisis: Country-specific and systemic issues, Princeton Studies in International Finance No. 84.

Ca' Zorzi, M., De Santis, R. (2004) Currency unions and the real exchange rate, Economics Letters, 85, 23-27.

Ca' Zorzi, M., De Santis, R., Zampolli, F. (2005) Welfare implications of joining a currency union, ECB Working Paper No. 445.

Clavel, L., Rüffer, R., Sánchez, M., Shen, J.-G. (2005) Emerging Asia's Growth and Integration: How autonomous are business cycles?, Paper to the Pacific Rim Conference, Hong Kong, January.

Eichengreen, B. (2004) Financial development in Asia: The way forward, Manuscript. University of California, Berkeley.

Eichengreen, B., Bayoumi, T. (1999) Is Asia an optimum currency area? Can it become one? Regional, global and historical perspectives on Asian monetary relations, in Exchange rate policies in Emerging Asian countries. Edited by Collignon, S., PisaniFerry, J., Park, Y., Routledge, London and New York, 347-366.

Faust, J., Leeper, E., (1997) When do long-run identifying restrictions give reliable results?, Journal of Business and Economic Statistics, 15, 345-353.

Frankel, J., Rose, A. (1998) The endogeneity of the optimum currency area criteria, Economic Journal, 108, 1009-1025.

Girardin, E. (2005) Growth-cycle features of East Asian countries: Are they similar?, International Journal of Finance and Economics, 10, 143-156.

Hefeker, C., Nabor, A. (2005) China's role in East Asian monetary integration, International Journal of Finance and Economics, 10, 157-166.

Jiménez-Rodríguez, R., Sánchez, M. (2005) Oil price shocks and real GDP growth: Empirical evidence for some OECD countries, Applied Economics, 37, 201-228.

Kang, S., Kim, S., Wang, Y. (2005) The effects of the yen/dollar exchange rate on the Korean economy, International Journal of Finance and Economics, 10, 167-183. 
Kenen, P. (2000) Currency areas, policy domains, and the institutionalization of fixed exchange rates, Discussion Paper No. 467, Centre for Economic Performance, London School of Economics.

Kwack, S. (2005) Exchange rate and monetary regime options for regional cooperation in East Asia, Journal of Asian Economics, 16, 57-75.

Kwan, C. (2001) Yen bloc: Towards economic integration in Asia, Brookings, Washington, DC.

Kose, M., Otrok, C., Whiteman, C. (2003) International business cycles: World, region, and country-specific factors, American Economic Review, 93, 1216-1239.

Lam, C., Sánchez, M., Tan, T. (2004) Trade between the EMEAP region and the euro area, Background paper to High Level Seminar between EMEAP and Eurosystem Central Banks, Singapore, July.

Lane, P. (2000) Asymmetric shocks and monetary policy in a currency union, Scandinavian Journal of Economics, 102, 585-604.

Lee, J., Park, Y., Shin, K. (2004) A currency union for East Asia, in Monetary and financial integration in East Asia: The way ahead. Edited by Asian Development Bank, Palgrave Macmillan, New York.

McKinnon, R., Schnabl, G. (2003) Synchronized business cycles in East Asia and fluctuations in the yen--dollar exchange rate, The World Economy, 26, 1067-89.

McKinnon, R., Schnabl, G. (2004) The return to soft dollar pegging in East Asia: Mitigating conflicted virtue, International Finance, 7, 169-201.

Mundell, R. (2002) Does Asia need a common currency market?, Pacific Economic Review, 7, 3-12.

Mussa, M., Masson, P., Swoboda, A., Jadresic, E., Mauro, P., Berg, A. (2000) Exchange rate regimes in an increasingly integrated world economy, IMF Occasional Paper No. 193.

Ogawa, E., Ito, T. (2002) On the desirability of a regional basket currency arrangement, Journal of Japanese and International Economies, 16, 317-334.

Plummer, M., Click, R. (2005) Bond market development and integration in ASEAN, International Journal of Finance and Economics, 10, 133-142.

Rumbaugh, T., Blancher, N. (2004) China: Growth in international trade and WTO accession, IMF Working Paper No. 36.

Rose, A. (2000) One money, one market: Estimating the effect of common currencies on trade, Economic Policy, 15, 7-46.

Rose, A. (2001) Currency unions and trade: The effect is large, Economic Policy, 16, 433462.

Rose, A. (2004) A meta-analysis of the effect of common currencies on international trade, NBER Working Paper No. 10373.

Sánchez, M. (2005a) Is time ripe for a currency union in Emerging East Asia?: The role of monetary stabilisation, ECB Working Paper No. 569.

Sánchez, M. (2005a) Monetary stabilisation in currency unions of small open economies, Manuscript, European Central Bank, Frankfurt. 
Williamson, J. (2002) The case for a basket, band and crawl regime for East Asia, in Future directions for monetary policies in East Asia. Edited by Gruen, D., Simon, J., Reserve Bank of Australia, Sydney, 96-111.

Wyplosz, C. (2002) A monetary union in Asia? Some European lessons, in Future directions for monetary policies in East Asia. Edited by Gruen, D., Simon, J., Reserve Bank of Australia, Sydney, 124-155. 